\title{
Реологические свойства композитов на основе бентонитовой глины и смесей полиэтилена высокой и низкой плотности
}

\section{Rheological properties of composites based on bentonite clay and mixture of high and low density polyethylene}

\section{Ф. А. Мустафаева}

Институт Полимерных Материалов

Национальной Академии Наук Азербайджана

\section{F. A. Mustafayeva}

Institute of Polymer Materials

of the Azerbaijan National Academy of Sciences

Поступила в редакцию 25.09.2019, принята к печати 28.10.2019

\section{Абстракт}

В статье приводятся результаты исследования реологических характеристик композитов, полученных на основе бентонитовой глины и смесей полиэтилена высокой и низкой плотности. Установлено влияние концентрации бентонита, температуры и напряжения сдвига на закономерность изменения эффективной вязкости и скорости сдвига, определена энергия активации и показатель текучести расплава композитов. Все композитные материалы были на основе смесей полиэтилена высокой и низкой плотности, взятых в соотношении 50/50. Исследования проводились с образцами, содержащими 1, 3, 5, 10, 20 и 30 масс. \% бентонита.

\section{Abstract}

The article presents the results of a study of the rheological characteristics of composites obtained on the basis of bentonite clay and mixtures of high and low density polyethylene. The influence of bentonite concentration, temperature and shear stress on the regularity of change in effective viscosity and shear rate was established, the activation energy and melt flow index of the composites were determined. All composite materials were based on mixtures of high and low density polyethylene taken in a ratio of 50/50. Studies were carried out with samples containing 1, 3, 5, 10, 20 and $30 \mathrm{wt}$. \% of bentonite.

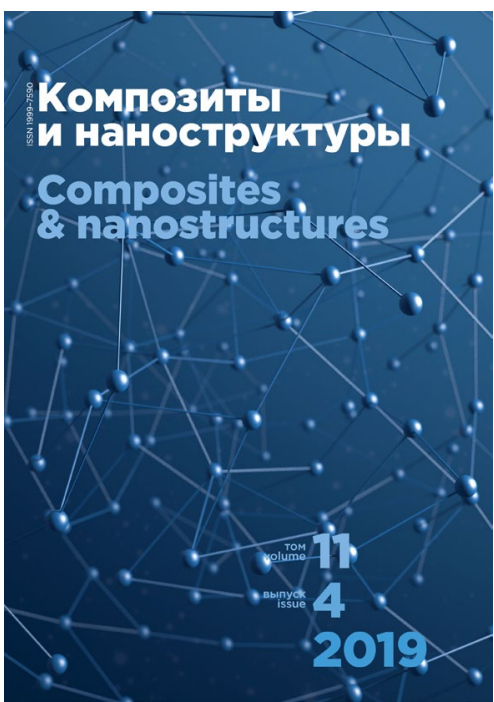

